\title{
Genetic Variation of mtDNA Cytochrome Oxidase Subunit I (COI) in Local Swamp Buffaloes in Indonesia
}

\author{
F. Saputra ${ }^{a, *}$, Jakaria $^{b}, \&$ C. Sumantri ${ }^{b}$ \\ aMajor Program of Animal Science Production and Technology, Graduate School, Bogor Agricultural University \\ bDepartment of Animal Production and Technology, Faculty of Animal Science, Bogor Agricultural University \\ Jln. Agatis, Kampus IPB Darmaga, Bogor 16680, Indonesia \\ (Received 19-06-2013; Reviewed 18-09-2013; Accepted 26-01-2014)
}

\begin{abstract}
The objective of this research was to identify genetic variation of mitochondria DNA especially in cytochrome oxidase subunit I (COI) among population of Indonesian buffaloes. Samples of swamp buffaloes were collected from Aceh $(n=3)$, North Sumatra $(n=3)$, Riau $(n=3)$, Banten $(n=3)$, Central Java $(n=3)$, West Nusa Tenggara $(n=3)$ and South Sulawesi $(n=3)$, and riverine buffalo from North Sumatra $(n=1)$ out of group for comparison. Sequence of COI was analyzed using MEGA 5.10 software with neighbor-joining method kimura 2-parameter model to reconstruct phylogeny tree. The result showed that three haplotypes for swamp buffalo and one haplotype for riverine buffalo in Indonesia resulted from 41 polymorphic sites. This finding showed that the COI gene could be considered as a marker to distinguish among swamp buffaloes in Indonesia.
\end{abstract}

Key words: COI, filogeny, genetic variation, Indonesian buffaloes

\section{ABSTRAK}

Tujuan penelitian ini adalah untuk mengidentifikasi keragaman DNA mitokondria, khususnya pada daerah cytochrome oxidase subunit I (COI) pada delapan populasi kerbau lokal Indonesia. Sampel kerbau lumpur berasal dari Aceh $(n=3)$, Sumatra Utara $(n=3)$, Riau $(n=3)$, Banten $(n=3)$, Jawa Tengah $(n=3)$, Nusa Tenggara Barat $(n=3)$ dan Sulawesi Selatan $(n=3)$; dan sebagai pembanding digunakan kerbau sungai yang berasal dari Sumatra Utara $(n=1)$. Sekuen gen COI dianalisis menggunakan program MEGA 5.10 software dengan metoda neighbor-joining substitusi kimura 2 parameter untuk merekonstruksi pohon filogeni. Hasil penelitian menunjukkan adanya 41 situs polymorfime dan dapat dikelompokkan kedalam tiga haplotipe untuk kerbau lumpur dan satu haplotipe untuk kerbau sungai. Gen COI dapat dipakai sebagai penciri genetik untuk membedakan antar populasi kerbau di Indonesia.

Kata kunci: COI, filogeni, kerbau Indonesia, variasi genetik

\section{INTRODUCTION}

Indonesian animal genetic resources for buffaloes consist of swamp buffalo, riverine buffalo, spotted buffalo (toraja buffalo) and kalang buffalo (borneo buffalo) (Director General of Livestock Services, 2003). Riverine buffaloes were introduced into Indonesia from India. Spotted buffalo and kalang buffalo are Indonesian swamp buffalo breed. Indigenous buffalo in Indonesia is swamp buffalo. Characterization of buffalo breeds in Indonesia are usually just based on the phenotype information. Study of the genetic distance estimation of local swamp buffaloes through morphology analysis has been done (Anggraeni et al., 2011) and growth hormone

\footnotetext{
*Corresponding author:

E-mail: ferdy44saputra@gmail.com
}

genes variation (Sumantri et al., 2010). Genetic information is needed to assist in determining of buffalo breeds. Recent investigations have suggested mitochondrial DNA (mtDNA) as a tool for studying the taxonomy and evolution of animal populations. The cytochrome oxidase subunit I (COI) gene is a part of mtDNA. This gene was chosen because of its main role in metabolism and its presence is almost in all eukaryotes. Additionally, the size and structure of COI gene have been well conserved in the animal groups, a feature which makes it especially suitable for evolutionary studies (Lunt et al., 1996). COI is one of the most conserved mitochondrial protein-coding genes in animals (Mueller, 2006), and thus displays a better phylogeny signal (Wilson, 2010). COI has been known to be as DNA barcoding that been used very successfully in many animal. For examples, it has been differentiated species in birds (Herbert et al., 2004), chicken (Gao et al., 2011), cattle (Syed-Shabthar et al., 2013), 
Cricula trifenestrata (Suriana et al., 2012), lepidoptera (Wilson, 2010), beetles (Funk et al., 1995), some insect pests (Toda \& Murai, 2006) Mermerodes hamona moth (Hulrc et al., 2007), mosquito (Cywinska et al., 2006), and Thrips tabaci (Karimi et al., 2010).

COI variations between bird species averaged $7.93 \%$, whereas variation within species averaged $0.43 \%$ (Herbert et al. 2004). Genetic diversity of COI gene in Chinese chicken breed found seven haplotypes (Gao et al., 2011). Genetic diversity of COI gene in Indonesian buffalo has not been explored yet. This study was therefore aimed to identify genetic variation of mitochondria DNA especially in cytochrome oxidase subunit I (COI) among population of local swamp buffaloes in Indonesia.

\section{MATERIALS AND METHODS}

\section{DNA Materials}

Samples of blood swamp buffaloes were collected from Aceh $(n=3)$, North Sumatra $(n=3)$, Riau $(n=3)$, Banten $(n=3)$, Central Java $(n=3)$, West Nusa Tenggara $(n=3)$ and South Sulawesi $(n=3)$; and riverine buffalo from North Sumatra $(n=1)$ out of group for comparison. All samples were stored in vacutainer tube with EDTA. DNA extraction was performed by using phenol chloroform method (Sambrook \& Russel, 2001) and modified by Andreas et al. (2010), with the following procedure:

Sample preparation. The blood in the alcohol was as much as $200 \mu \mathrm{L}$. Sample was inserted to a $1.5 \mathrm{~mL}$ tube. Alcohol was eliminated from the sample by adding distilled water until $1000 \mu \mathrm{L}$, and left in room temperature for $20 \mathrm{~min}$. Then it was precipitated by centrifugation at a speed of $8000 \mathrm{rpm}$ for $5 \mathrm{~min}$.

Protein degradation. The samples were cleared from alcohol and added by $200 \mu \mathrm{L}$ 1x STE (sodium tris EDTA), $40 \mu \mathrm{L}$ sodium dosesil sulfate $10 \%$, and $20 \mu \mathrm{L}$ proteinase $\mathrm{K}(5 \mathrm{mg} / \mathrm{mL})$. The mixture ware incubated overnight at 55 ${ }^{\circ} \mathrm{C}$ temperature while shaken gently.

Organic material degradation. After incubated, samples were added by $400 \mu \mathrm{L}$ phenol solution, $400 \mu \mathrm{L}$ choloform: isoamyl alcohol (24:1), and $40 \mu \mathrm{L} 5 \mathrm{M} \mathrm{NaCl}$. Then, the mixture was shaken at room temperature for one hour.

DNA precipitation. Samples were centrifuged at a speed of $5000 \mathrm{rpm}$ for $10 \mathrm{~min}$ to separate the water phase with phenol phase. Water phase was transferred in a new tube with the volume measured. DNA molecules deposited by adding a $2 x$ volume of alcohol absolute and $0.1 \times$ volume of $5 \mathrm{M} \mathrm{NaCl}$. Then the mixture was incubated at a temperature of $-20^{\circ} \mathrm{C}$ over night. Subsequent DNA precipitation was by centrifugated at a speed of $12000 \mathrm{rpm}$ for 10 min. Obtained DNA precipitate was washed by 70\% alcohol, and then precipitated again. Precipitated DNA clean from alcohol restored by adding $100 \mu \mathrm{L}$ TE (Tris-EDTA). DNA samples were stored at $-20^{\circ} \mathrm{C}$ and ready for use.

\section{PCR Amplification and Sequencing}

Two pair of primer was designed by using PrimerBlast (http://www.ncbi.nlm.nih.gov/tools/primer-blast/) with reference of genbank accession numbers of NC_020615, EF536351, AY488491, AF547270, NC_006295 and AY702618 (Table 1). PCR amplification was carried out with $35 \mu \mathrm{L}$ PCR reaction containing of 50-100 ng sample DNA, 10 pmol Primer (Alpha DNA), $10 \mathrm{mM}$ dNTPs (Fermentas), $25 \mathrm{mM} \mathrm{MgCl}$ (Fermentas), 10xBuffer (Fermentas), and 2.5 U Taq Polymerase (Fermentas). The condition of thermal cycling consisted of pradenaturation at $95{ }^{\circ} \mathrm{C}$ for $5 \mathrm{~min}$, followed by 35 cycles of denaturation $95^{\circ} \mathrm{C}$ for $40 \mathrm{~s}$, annealing $60^{\circ} \mathrm{C}$ for $45 \mathrm{~s}$, and extension $72{ }^{\circ} \mathrm{C}$ for $1 \mathrm{~min}$. The final extension step was at $72{ }^{\circ} \mathrm{C}$ for $5 \mathrm{~min}$. Amplification was carried out in a thermal cycler (Geneamp 9700, AB System). PCR amplicons were visualized on $1.5 \%$ agarose gels in $0.5 \times$ TBE buffer containing $10 \%$ ethidium bromide at 100 volt for $45 \mathrm{~min}$ and visualized by UV transiluminator.

Sequencing analysis was carried out by sending PCR amplicon samples to a commercial service (1st BASE, Malaysia). Sequences were analyzed using MEGA 5.10 software (Tamura et al., 2011). Method of neighborjoining with kimura 2-parameter model was applied for reconstructing phylogeny tree.

\section{RESULTS AND DISCUSSION}

\section{DNA Amplification}

COI gene of the riverine buffalo and swamp buffalo has 1545 bp in length (according genbank accession number AF547270 and NC_006295). Primer FS2 amplified at position 6364 in the Cytochrome Oxidase Subunit I (COI) to position 7411 in the tRNA ${ }^{\text {Ser }}$ (according genbank accession number AF547270) with fragment prediction of $1047 \mathrm{bp}$ in length (Figure 1). Primer FS3 amplified at position 5948 to position 6729 in the COI

Table 1. Overlapping primer for COI gene

\begin{tabular}{clccc}
\hline Primer & \multicolumn{1}{c}{ Sequence $\left(5^{\prime}-3^{\prime}\right)$} & Size & \multicolumn{2}{c}{ Position* $^{*}$ Name of gene } \\
\hline \multirow{2}{*}{ FS2 } & F: CAG CGG GGG GAG GAG ATC CTA TTC TAT ACC & \multirow{2}{*}{$1047 \mathrm{bp}$} & $6364-6393$ & COI \\
& R: GCC TAG TTG TAT AGG GTA TGC CAT ATG AGA & & $7383-7411$ & tRNA \\
\multirow{2}{*}{ FS3 } & F: TCC CTC TAA TAA TTG GCG CTC CCG & $781 \mathrm{bp}$ & $5948-5971$ & COI \\
& R: GCC TAG GGC TCA CAT TAT AGC GGG & & $6706-6729$ & COI \\
\hline
\end{tabular}

Note: * according Genbank accession number AF547270 


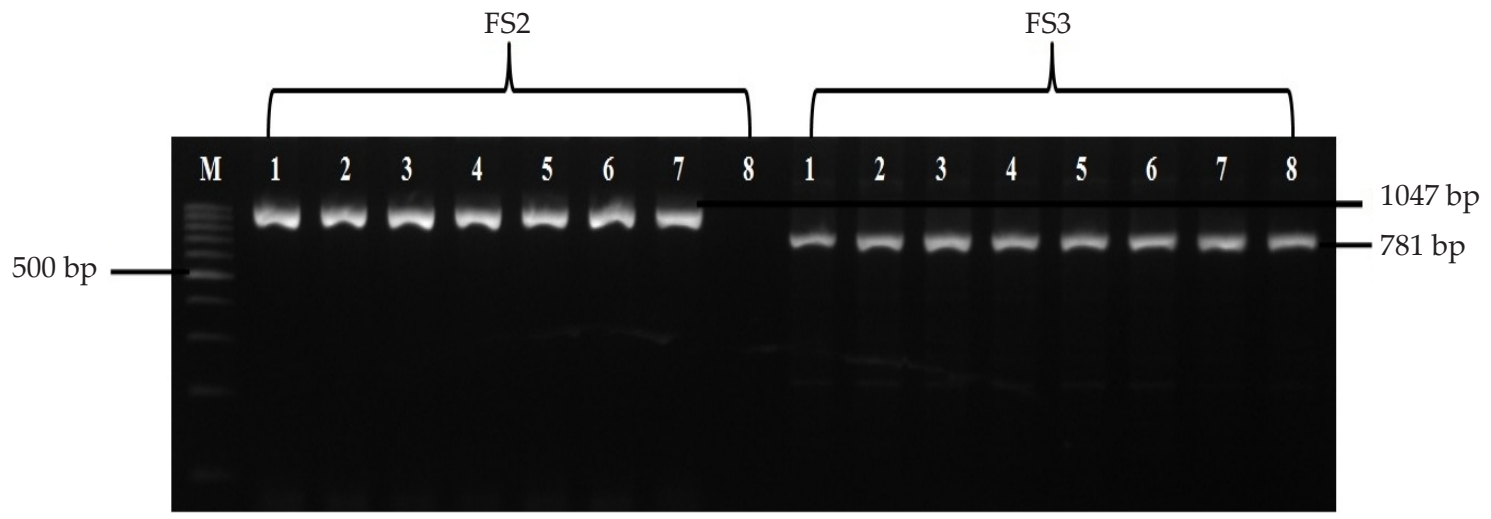

Figure 1. Cytochrome oxidase subunit I gene PCR product amplified from samples. M= 100 bp ladder size standard; $1=$ North Sumatra (river buffalo); 2= North Sumatra (swamp buffalo); 3= Riau (swamp buffalo); $4=$ Banten (swamp buffalo); $5=$ Central Java (swamp buffalo); 6= West Nusa Tenggara (swamp buffalo); $7=$ South Sulawesi (swamp buffalo); and 8= Aceh (swamp buffalo) (FS2 \& FS3= name of primer).

Table 2. Nucleotide composition of sequences of seven population of Indonesian local buffaloes and Genbank accession number

\begin{tabular}{|c|c|c|c|c|c|c|c|}
\hline \multirow{2}{*}{ Sample } & \multicolumn{6}{|c|}{$\%$} & \multirow{2}{*}{ Total } \\
\hline & $\mathrm{T}(\mathrm{U})$ & $\mathrm{C}$ & A & G & $\mathrm{T}+\mathrm{A}$ & $C+G$ & \\
\hline NC 020615.1 I Bubalus depressicornis & 29.4 & 26.0 & 27.6 & 17.0 & 57.0 & 44.6 & 1243 \\
\hline EF536351.1|Bubalus depressicornis & 29.4 & 26.0 & 27.6 & 17.0 & 57.0 & 44.6 & 1243 \\
\hline AY488491.1 | Riverine Buffalo & 29.6 & 25.7 & 28.0 & 16.7 & 57.6 & 42.4 & 1243 \\
\hline AF547270.1 | Riverine Buffalo & 30.1 & 25.3 & 27.9 & 16.7 & 58.0 & 42.0 & 1243 \\
\hline Riverine Buffalo North Sumatra 8 & 29.6 & 25.7 & 28.0 & 16.7 & 57.6 & 42.4 & 1243 \\
\hline NC 006295.1।Swamp Buffalo & 29.2 & 26.1 & 28.2 & 16.5 & 57.4 & 42.6 & 1243 \\
\hline AY702618.1ISwamp Buffalo breed Haikou & 29.2 & 26.1 & 28.2 & 16.5 & 57.4 & 42.6 & 1243 \\
\hline Swamp Buffalo Aceh 7 & 29.1 & 26.4 & 27.6 & 16.9 & 56.7 & 43.3 & 711 \\
\hline Swamp Buffalo Aceh 8 & 29.1 & 26.4 & 27.6 & 16.9 & 56.7 & 43.3 & 711 \\
\hline Swamp Buffalo Aceh 73 & 29.1 & 26.4 & 27.6 & 16.9 & 56.7 & 43.3 & 711 \\
\hline Swamp Buffalo North Sumatra 16 & 29.0 & 26.4 & 28.2 & 16.4 & 57.2 & 42.8 & 1243 \\
\hline Swamp Buffalo North Sumatra 21 & 29.0 & 26.4 & 28.0 & 16.7 & 57.0 & 43.0 & 1243 \\
\hline Swamp Buffalo North Sumatra 26 & 29.2 & 26.1 & 28.2 & 16.5 & 57.2 & 42.8 & 1243 \\
\hline Swamp Buffalo Riau 14 & 29.0 & 26.4 & 28.2 & 16.4 & 57.0 & 43.0 & 1243 \\
\hline Swamp Buffalo Riau 26 & 29.2 & 26.1 & 28.2 & 16.5 & 57.4 & 42.6 & 1243 \\
\hline Swamp Buffalo Riau 30 & 29.2 & 26.1 & 28.2 & 16.5 & 57.4 & 42.6 & 1243 \\
\hline Swamp Buffalo Banten 7 & 29.2 & 26.1 & 28.2 & 16.5 & 57.4 & 42.6 & 1243 \\
\hline Swamp Buffalo Banten 41 & 29.2 & 26.1 & 28.2 & 16.5 & 57.4 & 42.6 & 1243 \\
\hline Swamp Buffalo Banten 50 & 29.2 & 26.1 & 28.2 & 16.5 & 57.4 & 42.6 & 1243 \\
\hline Swamp Buffalo Central Java 4 & 29.2 & 26.1 & 28.2 & 16.5 & 57.4 & 42.6 & 1243 \\
\hline Swamp Buffalo Central Java 20 & 29.2 & 26.1 & 28.2 & 16.5 & 57.4 & 42.6 & 1243 \\
\hline Swamp Buffalo Central Java 16 & 29.2 & 26.1 & 28.2 & 16.5 & 57.4 & 42.6 & 1243 \\
\hline Swamp Buffalo West Nusa Tenggara 7 & 29.2 & 26.1 & 28.2 & 16.5 & 57.4 & 42.6 & 1243 \\
\hline Swamp Buffalo West Nusa Tenggara 13 & 29.2 & 26.1 & 28.2 & 16.5 & 57.4 & 42.6 & 1243 \\
\hline Swamp Buffalo West Nusa Tenggara 23 & 29.2 & 26.1 & 28.2 & 16.5 & 57.4 & 42.6 & 1243 \\
\hline Swamp Buffalo South Sulawesi 102 & 29.2 & 26.1 & 28.2 & 16.5 & 57.4 & 42.6 & 1243 \\
\hline Swamp Buffalo South Sulawesi 103 & 29.2 & 26.1 & 28.2 & 16.5 & 57.4 & 42.6 & 1243 \\
\hline Swamp Buffalo South Sulawesi 117 & 29.2 & 26.1 & 28.2 & 16.5 & 57.4 & 42.6 & 1243 \\
\hline
\end{tabular}


Table 3. Haplotype and polymorphic site

\begin{tabular}{|c|c|c|c|c|c|c|c|c|c|c|c|c|c|c|c|c|c|c|c|c|c|c|c|c|c|c|c|c|c|c|c|c|c|c|c|c|c|c|c|c|c|}
\hline \multirow{5}{*}{$\mathrm{H}$} & \multicolumn{41}{|c|}{ Nucleotide position* (bp) } \\
\hline & 3 & 3 & 3 & 3 & 3 & 3 & 3 & 3 & 3 & 4 & 4 & 4 & 4 & 4 & 4 & 4 & 4 & 5 & 5 & 5 & 6 & 6 & 6 & 7 & 7 & 7 & 8 & 8 & 8 & 8 & 9 & 1 & 1 & 1 & 1 & 1 & 1 & 1 & 1 & 1 & \\
\hline & 3 & 4 & 5 & 7 & 7 & 7 & 8 & 8 & 9 & 0 & 1 & 1 & 2 & 2 & 5 & 5 & 7 & 1 & 4 & 5 & 0 & 1 & 6 & 1 & 3 & 5 & 0 & 0 & 4 & 7 & 3 & 0 & 0 & 0 & 1 & 1 & 4 & 4 & 4 & 4 & 5 \\
\hline & & & & & & & & & & & & & & & & & & & & & & & & & & & & & & & & 3 & 3 & 8 & 3 & 9 & 0 & 1 & 2 & 5 & 1 \\
\hline & 6 & 8 & 4 & 3 & 5 & 8 & 2 & 4 & 8 & 2 & 0 & 5 & 1 & 3 & 6 & 8 & 5 & 0 & 6 & 5 & 3 & 8 & 3 & 7 & 8 & 0 & 4 & 7 & 6 & 0 & 9 & 2 & 8 & 3 & 1 & 7 & 1 & 3 & 2 & 2 & 5 \\
\hline $\mathrm{H} 1$ & C & C & $\mathrm{T}$ & G & $\mathrm{T}$ & G & G & A & $C$ & $\mathrm{~T}$ & C & G & G & $\mathrm{T}$ & G & $C$ & $\mathrm{~T}$ & $\mathrm{C}$ & $C$ & A & A & $C$ & $\mathrm{~T}$ & G & $\mathrm{T}$ & A & $\mathrm{T}$ & A & $\mathrm{C}$ & $C$ & $C$ & $\mathrm{~T}$ & C & C & C & G & A & $C$ & $\mathrm{~A}$ & $\mathrm{C}$ & $\mathrm{T}$ \\
\hline $\mathrm{H} 2$ & · & . & . & . &. & . & . & . & . & . & . & . & . & . & . & . & . & . & . & $\mathrm{T}$ & r & $\theta^{\circ}$ & 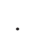 & . & . & . & 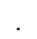 & e & 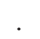 & $\theta^{\circ}$ & . & - & - & - & - & - & - & - & - & - & - \\
\hline H3 & . & . & G & C & G & . & $\mathrm{C}$ & $\mathrm{T}$ & G & C & G & C & C & . & . & $\mathrm{G}$ & . & . & . & . & . & $\mathrm{T}$ & $\mathrm{C}$ & . & . & . & . & G & $\mathrm{T}$ & . & . & C & . & . & . & . & 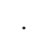 & . & . & . & . \\
\hline $\mathrm{H} 4$ & & . & . & . & 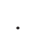 & . & . & . & . & . & . & . & . & . & . & . & . & . & . & . & . & . & . & . & . & . & $\cdot$ & . & . & r. & . & C & ${ }^{\circ}$ & $\cdot$ & . & C & . & . & . & . & C \\
\hline H5 & $\mathrm{T}$ & $\mathrm{T}$ & & . & . & A & . & . & 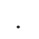 & 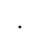 & 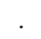 & 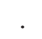 & . & C & A & . & C & $\mathrm{T}$ & $\mathrm{T}$ & G & G & $\mathrm{T}$ & . & A & C & G & C & . & $\mathrm{T}$ & $\mathrm{T}$ & $\mathrm{T}$ & C & $\mathrm{T}$ & $\mathrm{T}$ & $\mathrm{T}$ & . & G & $\mathrm{T}$ & G & . & 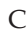 \\
\hline
\end{tabular}

Note: *according buffalo COI gene ( $\mathrm{H}$ is haplotype)

(according genbank accession number AF547270) with fragment prediction of $781 \mathrm{bp}$ in length (Figure 1). Aceh samples not amplified using primer FS2 but amplified using primer FS3 (Figure 1).

\section{Sequence Variation and Haplotype Sharing}

Nucleotide composition of sequences (Table 2) showed a slight difference in the nucleotide composition of the sample. It is especially in Swamp Buffalo North Sumatra 16, Swamp Buffalo North Sumatra 21 and Swamp Buffalo Riau 14. Genetic variation at mitochondrial D-loop region in Egyptian river buffalo showed 28 different haplotypes resulting from 77 polymorphic sites (Hassan et al., 2009). In this research at mitochondrial Cytochrome Oxidase subunit I (COI) showed four haplotypes for local swamp buffaloes in Indonesia resulted from 41 polymorphic sites (Table 3 ).

The first haplotype consisted of Banten Samples, South Sulawesi Samples, West Nusa Tenggara Samples,
Central Java Samples, Riau 30, Riau 26, North Sumatra 26, NC_006295.1 and AY702618.1. The second haplotype consisted of Aceh samples. The third haplotype was North Sumatra 21. The fourth haplotype consisted of North Sumatra 16 and Riau 14. The fifth haplotype consisted of North Sumatra 8 (River Buffalo) and AF547270 (River Buffalo). A unique sequence of North Sumatra 21 (Swamp buffalo) has many nucleotide differences (Table 3). As a result, the sample is separated from the swamp buffalo group (Figure 2).

Genetic variation was found in swamp Buffalo population in Aceh (with blue highlight color) at position $555 \mathrm{bp}$ in cytochrome oxidase subunit I (Figure 2). Nucleotide at positition $555 \mathrm{bp}$ encoded with thymine (T) called haplotype 2. This haplotype only found in Swamp Buffalo population in Aceh (Figure 2 and Table 3). Swamp Buffalo in Aceh is possibility of indigenous buffalo in Indonesia although only one nucleotide difference. This requires further research to prove this hypothesis. Phylogeny tree (Figure 3) showed no genetic
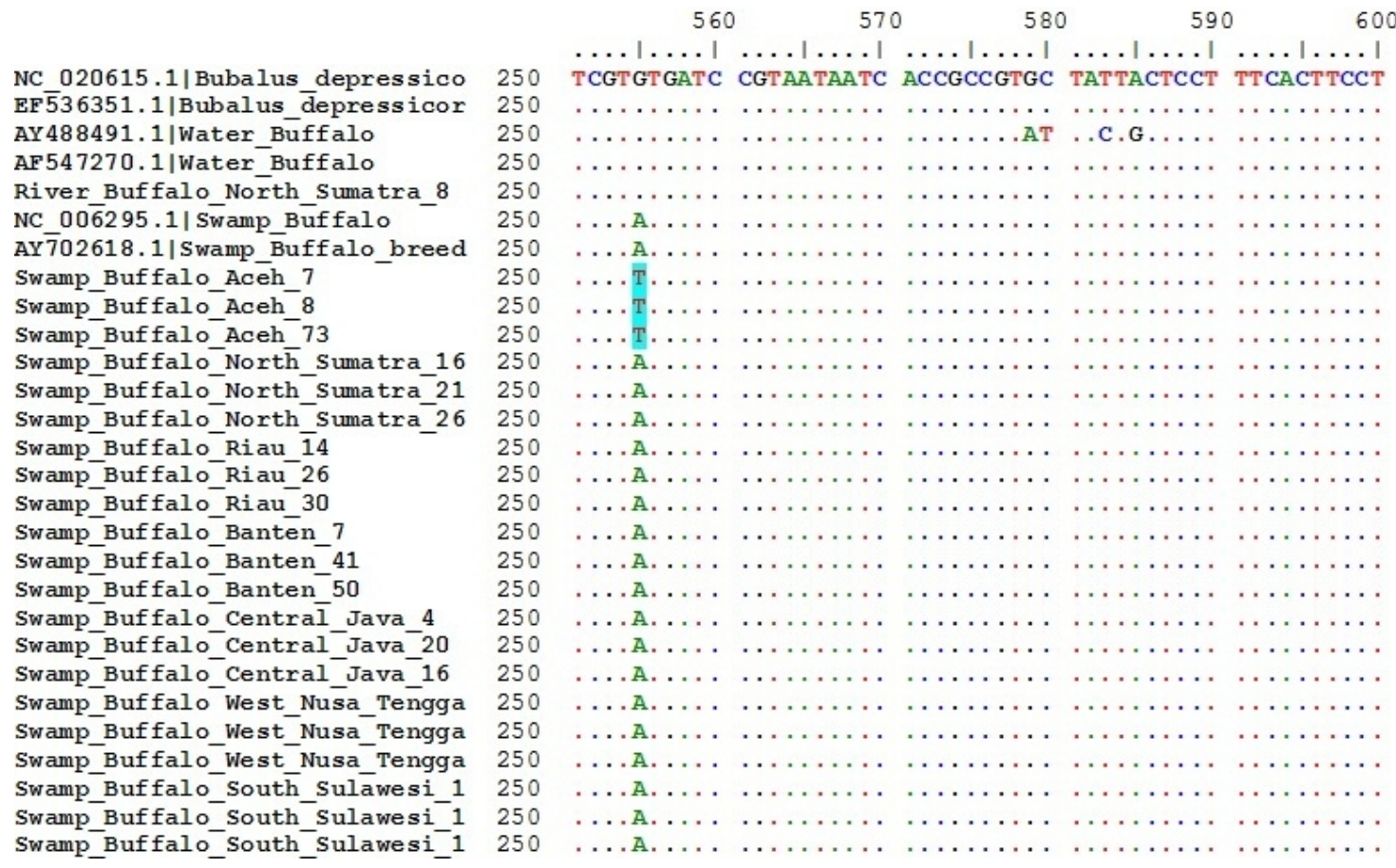

Figure 2. Sequence of cytochrome oxidase subunit I gene 


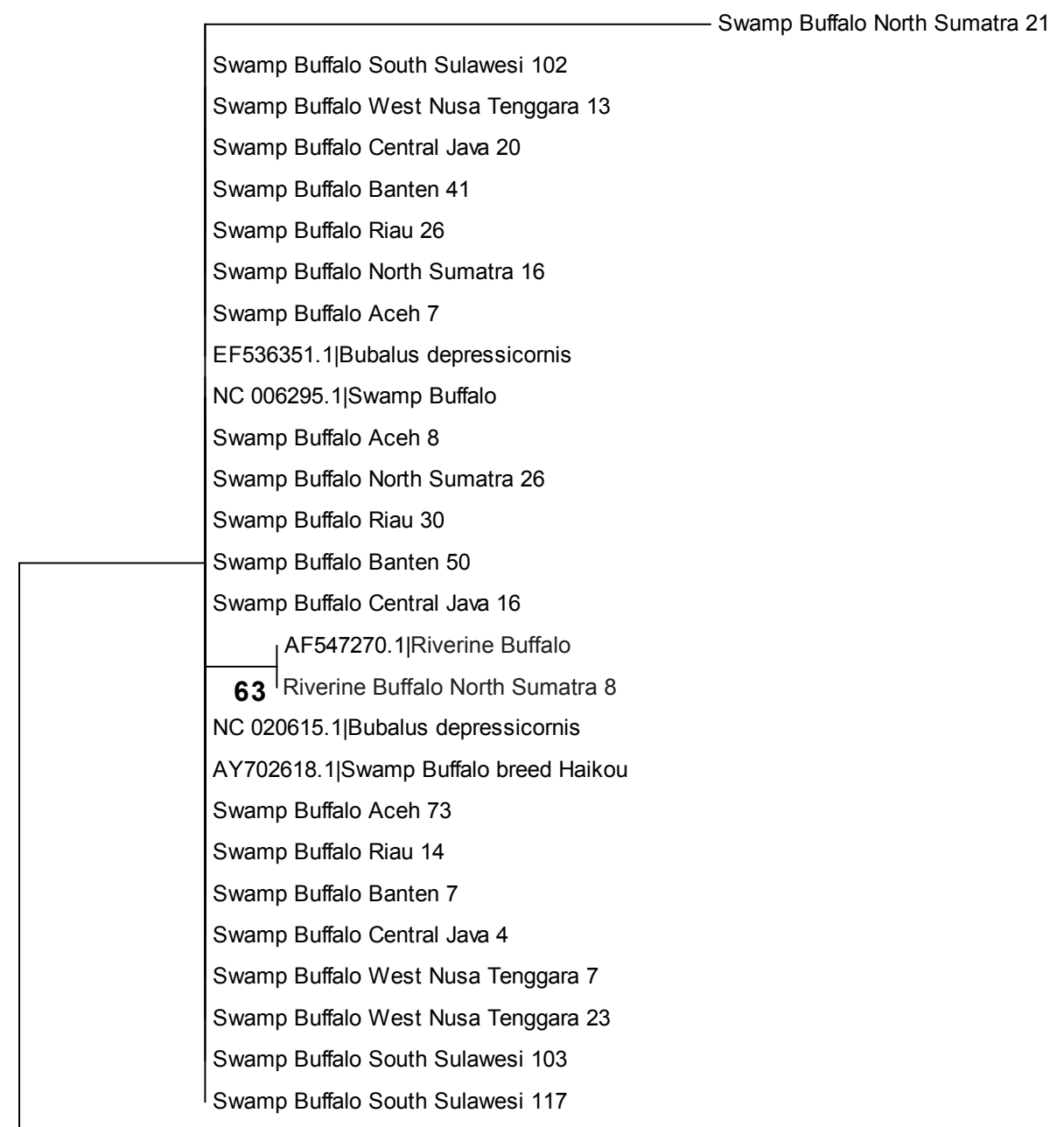

AY488491.1|Riverine Buffalo

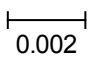

Figure 3. The phenogram tree according to cytochrome oxidase subunit I of eight population of Indonesian local buffaloes

differences between Indonesian swamp buffaloes with Chinese swamp buffaloes. This finding suggests those Indonesian swamp buffaloes are very closely related to swamp buffaloes in China. This present result supports that swamp buffaloes are the result of buffalo domestication in China (Kumar et al., 2007). Historical data of local swamp buffaloes in Indonesia are not available, so that it cannot explain the genetic relationship between the buffaloes in Aceh, Banten, Central Java, West Nusa Tenggara and South Sulawesi with swamp buffalo in China. Genetic variation at mitochondrial DNA D-loop and cytohrome $b$ sequence showed eight haplotypes for D-loop mitochondria in Bogor and South Sulawesi and one haplotype for cytochome b in Bogor and South Sulawesi (Lau et al., 1998). This results support the following hypothesis domestication of swamp buffalo in china spread with rice cultivation through two separate routes (a) through Taiwan, to the Philippines and to the eastern islands of Borneo and Sulawesi, (b) south through mainland south-east Asia (likely interbreeding with wild buffalo) to peninsular Malaysia and on to the western island of Sumatra and Java (Lau et al., 1998).
Lei et al. (2007) found 12 haplotype of mtDNA D-loop Chinese swamp buffaloes and two maternal linages. Kierstein et al. (2004) found "unique group" based on mtDNA D-loop with assumpsion during migration to Indochina and South-East Asia occasional cross-breeding with wild buffaloes could have lead to those haplotypes now found in the "unique group", intermixing with the haplotypes of the founder population of domestic riverine buffaloes. Based on our results we hypothesize a "unique sequence" (Third haplotype) based on COI gene assuming the same happens with assumption of Kierstein et al. (2004). To clarify a "unique sequence", it is necessary to conduct more samples of local swamp buffaloes in Indonesia. Phylogeny tree shows the difference between river buffalo with swamp buffalo (Figure 3).

\section{CONCLUSION}

This research find three haplotypes in the cytochrome oxidase subunit I (COI) gene of local swamp buffaloes resulted from 41 polymorphic sites. The COI 
gene could be considered as a marker to distinguish among swamp buffaloes in Indonesia. However, this study has to be validated in large buffaloes populations in order to evaluate its potential in selective breeding.

\section{REFERENCES}

Andreas, E., C. Sumantri, H. Nuraini, A. Farahjallah, \& A. Anggraeni. 2010. Identification of $\mathrm{GH} / A l u \mathrm{I}$ and $\mathrm{GHR} / A l u \mathrm{I}$ genes polymorphism in Indonesian Buffalo. JITAA. 35: 215-221.

Anggraeni, A., Sumantri C, Praharani L, Dudi, \& Andreas E. 2011. Estimasi jarak genetik kerbau rawa lokal melalui pendekatan analisis morfologi. JITV 16: 199-210.

Cywinska, A. C., F. F. Hunter, \& P. D. N. Hebert. 2006. Identifying Canadian mosquito species through DNA barcodes. Med. Veter. Entomol. 20:413-424. http://dx.doi.org/10.1111/ j.1365-2915.2006.00653.x

Director General of Livestock. 2003. National report on animal genetic resources Indonesia. A Strategic Policy Document. FAO.

Funk, D. J., D. J. Futuyma, G. Orti, \& A. Meyer. 1995. Mitochondrial DNA sequence and multiple data sets: A phylogenetic study of phyotophagus beetles (Chrysomelidae: Ophraella). Mol. Biol. Evol. 12: 627-640.

Gao, Y. S., Y J Tu, J. X. Lu, \& X. Y. Zhang. 2011. Studies on the DNA barcoding of two newly discovered chicken breeds by mtDNA COI gene. J Anim Vet Adv. 10: 1711-1713. http://dx.doi.org/10.3923/javaa.2011.1711.1713

Hassan, A. A., S. M. El Nahas, S. Kumar, P. S. Godithala, \& Kh. Roushdy. 2009. Mitochondrial D-loop nucleotide sequences of Egyptian river buffalo: Variation and phylogeny studies. J. Livsci. 125: 37-42.

Hebert, P. D. N., M. Y. Stoeckle, T. S. Zemlak, \& C. M. Francis. 2004. Identification of Birds through DNA Barcodes. PLoS Biol. 2: e312. http://dx.doi.org/10.1371/journal. pbio.0020312

Hulrc, J., S. C. Miller, G. P. S. K. Darrow, D. N. Muller, P. D. N. Hebert, \& G. D. Weiblen. 2007. DNA barcoding confirms polyphagy in a generalist moth, Hontona mermerodes (Lepidoptera: Tortricidae). Mol. Ecol. 7:549-557.

Karimi, J., M. H. Kakhki, \& M. Modarres. 2010. Identifying thrips (Insecta: Thysanoptera) using DNA barcodes. J. Cell Mol. Res. 2: 35-41.

Kierstein, G., M. Vallinoto, A. Silva, M. P. Schneider, L. Iannuzzi, \& B. Breniga. 2004. Analysis of mitochondrial Dloop region casts new light on domestic water buffalo (Bubalus bubalis) phylogeny. Mol. Phylogenet. Evol. 30: 308-32. http://dx.doi.org/10.1016/S1055-7903(03)00221-5

Kumar, S., J. S. Sandhu, N. Kumar, V. Behl, \& G. Nishanth. 2007. Mitochondrial DNA analyses of Indian water buffalo support a distinct genetic origin of river and swamp buffalo. Anim Genet. 8: 227-32. http://dx.doi.org/10.1111/ j.1365-2052.2007.01602.x

Lau, C. H., R. D. Drinkwater, K.Yusoff, S. G. Tan, D. J. Hetzel, \& J. S. Barker. 1998. Genetic diversity of Asian water buffalo (Bubalus bubalis): mitochondrial DNA D-loop and cytochrome b sequence variation. Anim Genet. 29: 253-64. http://dx.doi.org/10.1046/j.1365-2052.1998.00309.x

Lei, CZ., W. Zhang, H. Chen, F. Lu, Q. L. Ge, R. Y. Liu, R. H. Dang, Y. Y. Yao, L. B. Yao, Z. F. Lu, \& Z. L. Zhao. 2007. Two Maternal Lineages Revealed by Mitochondrial DNA D-loop Sequences in Chinese Native Water Buffaloes (Bubalus bubalis). Asian-Aust. J. Anim. Sci. 20: 471-476

Lunt, D. H., D. S. Zhang, D. M. Zhimura, \& G. M. Dewit. 1996. The insect cytochrome oxidase I gene: evolutionary pattern and conserve primer for phylogenetics studies. Insect. Mol. Biol. 5:153-165. http://dx.doi.org/10.1111/j.13652583.1996.tb00049.x

Mueller, R. L. 2006. Evolutionary rates, divergence dates, and the performance of mitochondrial genes in Bayesian phylogenetic analysis. Syst. Biol. 55: 289-300. http://dx.doi. org/10.1080/10635150500541672

Sambrook, J. \& D. W. Russell. 2001. Molecular Cloning: A Laboratory Manual, $3^{\text {rd }}$ ed. Cold Spring Harbor Laboratory Press. New York, USA.

Sumantri, C., R. Diyono, A. Farajallah, A. Anggraeni \& E. Andreas. 2010. Pemanfaatan famili gen hormon pertumbuhan (GH, GHR, GHRH dan PIT-1) untuk mendeteksi keragaman genetik kerbau di Kabupaten Pandeglang dan Lebak Provinsi Banten. JITV. 15:286-296.

Suriana, D., D. Solihin, R. R. Noor, \& A. M. Thohari. 2012. The Characteristics of Cytochrome C Oxidase Gene Subunit I in Wild Silkmoth Cricula trifenestrata Helfer and Its Evaluation for Species Marker. Med. Pet. 35: 102-110. http:// dx.doi.org/10.5398/medpet.2012.35.2.102

Syed-Shabthar, S. M., M. K. Rosli, N. A. Mohd-Zin, S. M. Romaino, Z. A. Fazly-Ann, M. C. Mahani, O. Abas-Mazni, R. Zainuddin, S. Yaakop, \& B. M. Md-Zain. 2013. The molecular phyogenetic signature of Bali cattle revealed by maternal and paternal markers. Mol Biol Rep. [Epub ahead to print] http://dx.doi.org/10.1007/s11033-013-2619-y

Tamura, K., J. Dudley, M. Nei \& S. Kumar. 2011. MEGA software (version 5) : Molecular Evolutionary Genetics Analysis. Center of Evolutionary Functional Genomics Biodesign Institute. Arizona State University.

Toda, S. \& T. Murai. 2006. Phylogenetic analysis based on mitochondrial COI gene sequences in Thripstabaci Lindeman (Thysanoptera: Thripidae) in relation to reproductive forms and geographic distribution. Appl. Entomol. Zool. 42: 309-316. http://dx.doi.org/10.1303/aez.2007.309

Wilson, J. J. 2010. Assessing the value of DNA barcodes and other priority gene regions for molecular phylogenetics of Lepidoptera. Plos One 5: e10525. http://dx.doi.org/10.1371/ journal.pone.0010525 